\title{
Comparison of Canadian and American Graduate Evaluation Education Programs
}

\author{
M. Theresa Hunter and James C. McDavid \\ University of Victoria
}

\begin{abstract}
University education in evaluation is an important support for the professionalization of the field. Using internet sources and direct contacts with 105 Canadian university departments, our study develops a Canada-wide inventory of graduate courses and programs, with emphasis on evaluation. Comparisons are made with inventories of American graduate evaluation programs undertaken between 1980 and 2018. Although Canada has about half as many multi-course graduate programs in evaluation as were found in the United States in 2018, the relative number of Canadian programs is disproportionately greater, considering the two countries' population sizes. Canada also has a more diverse range of disciplines offering evaluation education programs.
\end{abstract}

Keywords: Canada-US comparisons, evaluation education, inventory, professionalization

Résumé : La formation universitaire en évaluation contribue significativement à sa professionnalisation. La présente étude visait à développer un inventaire pancanadien des programmes et des cours en l'évaluation, et ce, aux cycles supérieurs. La collecte de données a permis de rejoindre 105 départements universitaires en ayant recours aux informations disponibles sur les sites internet ou en contactant des personnes-ressources. Des comparaisons ont été effectuées avec les recensements des programmes d'évaluation américains aux cycles supérieurs entre 1980 et 2018. Bien que le Canada compte environ deux fois moins de programmes aux cycles supérieurs offrant plusieurs cours en évaluation comparativement aux États-Unis en 2018, le nombre relatif de ses programmes est beaucoup plus élevé si nous tenons compte de la taille des deux populations. De plus, le Canada possède également un éventail plus diversifié de disciplines offrant une formation en évaluation de programme.

Mots clé : comparaisons Canada - États-Unis, formation en évaluation, inventaire, professionnalisation

\section{BACKGROUND}

The evaluation field has grown significantly since the 1950s and 1960s, when it was first recognized as a distinct field (Worthen, 1990). Supports for the professionalization

Corresponding author: $\mathrm{M}$. Theresa Hunter, School of Public Administration, University of Victoria, PO Box 1700 STN CSC, Victoria, BC V8W 2Y2; thunter@uvic.ca

๑) 2019 Canadian Journal of Program Evaluation / La Revue canadienne d'évaluation de programme 34.2 (Fall / automne), 207-234 doi: 10.3138/cjpe.56989 
of evaluation practice have included a growing number of professional associations (LaVelle \& Donaldson, 2015), codes of ethics and program evaluation standards (Yarbrough, Shulha, Hopson, \& Caruthers, 2011), dedicated journals, listservs (such as the one hosted by the American Evaluation Association [AEA EvalTalk since 1995]), pre-service and in-service training (both credit and non-credit), as well as regional, national, and international conferences. University graduate education in evaluation is one type of support for the professionalization of the field. Inventories of evaluation courses and programs have been undertaken periodically to track the number of evaluation education programs in the United States and internationally (Altschuld, Engle, Cullen, Kim, \& Macce, 1994; Conner, Clay, \& Hill, 1980; Engle, Altschuld, \& Kim, 2006; LaVelle \& Donaldson, 2010; May, Fleischer, Scheirer, \& Cox, 1986; Stockmann \& Meyer, 2016). A preliminary inventory of graduate evaluation courses and programs offered in Canada was conducted by Devine and McDavid in 2009, on behalf of the Consortium of Universities for Evaluation Education (CUEE).

The main purpose of the current study was to identify graduate courses and programs with emphasis on program evaluation offered at universities across Canada. Research questions included the following: how does the Canadian landscape of evaluation education compare with similar inventories of programs in the United States? The full 2018 Inventory of Canadian Graduate Evaluation Education courses and programs is a rich resource for CUEE members, the Canadian Evaluation Society (CES), and others who share an interest in graduate evaluation education. This inventory also provides a baseline for future studies and ongoing monitoring of trends in Canadian evaluation education.

Supports for the professionalization of evaluation in Canada have grown a great deal over the years. Since 1981, CES has grown substantially in its membership and support activities toward the professionalization of evaluation in Canada (CES, n.d.b). CES has held annual conferences since 1980, began publishing The Canadian Journal of Program Evaluation in 1986, and has developed and updated professional standards and code of ethics. CES has offered in-service Essential Skills Series since 1999 and continues to update this program and aims to develop more advanced levels of training. CES has offered online webinars since 2012 and created the e-Institute in 2016, to augment online learning opportunities for its members.

A unique feature of the professionalization of evaluation in Canada is the Credentialed Evaluator (CE) designation, established by CES in 2009. The CE designation formally acknowledges professional evaluators' competency in knowledge, skills, experience, commitment, and ongoing learning (CES, n.d.a). A graduate level degree or certificate is a requirement to obtain the CE designation, and curricula that emphasize program evaluation are very desirable (CES, 2010).

In 2008, university partners, in collaboration with CES and the federal government, established the Consortium of Universities for Evaluation Education (CUEE) with the aim of building capacity and expanding opportunities for graduate-level education and training in evaluation across Canada (CUEE, n.d.). 
For the past ten years, CUEE has maintained a membership of approximately a dozen universities, representing a diverse range of graduate programs that deliver courses in evaluation in various disciplines, including psychology, education, public administration, and medicine. A growing number of CUEE members offer graduate certificate and diploma credentials in evaluation. These intensive programs help graduates satisfy the requirement for education and training to qualify for the CE designation. While a number of graduate programs offer students the opportunity to specialize in evaluation within their courses of study, opportunities to complete a graduate degree in evaluation are very limited in Canada.

\section{INVENTORIES OF UNIVERSITY-BASED EVALUATION EDUCATION PROGRAMS IN THE UNITED STATES}

Periodic studies of university-based evaluation education programs have been undertaken in the United States over the past 40 years (Altschuld et al., 1994; Conner et al., 1980; Engle et al., 2006; LaVelle, 2018; LaVelle \& Donaldson, 2010; May et al., 1986). American researchers built upon one another's studies to track the evolution of university-based programs in evaluation at different points in time. Early studies used survey methods to collect data about evaluation courses and education programs, whereas, in later years, the Internet became an important tool in gathering information (e.g., Engle et al., 2006; LaVelle \& Donaldson, 2010; LaVelle, 2014, 2018).

American researchers defined a "program" of study in evaluation as "multiple courses, seminars, practicums, offerings, and so on designed to teach evaluation principles and concepts" (Altschuld et al., 1994, p. 72). This definition of "program" was further refined by Engle et al. (2006) and LaVelle and Donaldson (2010) to include university departmental units that offered graduate degree programs with two or more courses with a major emphasis on evaluation. Altschuld et al. (1994) used various methods to construct their initial sampling frame of potential academic programs in evaluation, such as examining lists of programs identified in earlier studies and consulting with representatives of professional associations, including AEA, CES, and the American Sociological Association (ASA). They then conducted a survey to gather detailed information about university graduate evaluation programs in the United States, Canada, and Australia. With an $83 \%$ response rate, 49 programs of study were confirmed, including 38 in the United States and 11 in Canada and Australia. These researchers confirmed fewer programs in 1993 in the United States (38) compared with the 44 identified in an earlier study by May et al. (1986), and more in Canada and Australia (11 vs. two in 1986, including nine Canadian universities, one Government of Canada, and one in Australia). Most university evaluation education programs (76\%) offered both doctoral and master's degrees, while others (14\%) offered a master's degree only. Altschuld et al. (1994) also identified changes in the disciplinary location of evaluation education programs, confirming $67 \%$ of programs in the disciplines of education, educational psychology, or psychology, compared 
with $85 \%$ of programs in these disciplines in 1986 . Using the number of courses offered as a proxy for program size, Altschuld et al. (1994) identified 15 (30.6\%) small (2-3 courses), 13 (26.5\%) medium-sized (4-6 courses), and 21 (42.9\%) large $(7+$ courses $)$ programs.

In a more recent study, Engle et al. (2006) used both a survey and online searches between 2000 and 2002 to gather information about programs of study in evaluation. They sent 84 surveys to candidate programs for which they had contact information (63 US; 23 international), requesting details regarding degrees offered, number of students and their demographics, program FTEs, course descriptions, program goals, areas of specialization, inclusion of evaluation standards, practical experience, and so on. Thirty-eight surveys were returned (45\% response rate); however, Engle et al. confirmed just 29 graduate programs in evaluation ( 24 in the US and five internationally), representing a $41 \%$ decline compared with the earlier study (Altschuld et al., 1994). Among these findings were more small programs (19;65.5\%), fewer medium-sized programs $(9 ; 31.0 \%)$, and far fewer large programs $(1 ; 3.4 \%)$ than identified in the 1993 survey.

LaVelle and Donaldson (2010) undertook internet searches in 2008 to investigate whether the number of graduate evaluation education programs in the United States was actually in decline. They used a modified definition of "program" to identify university graduate evaluation courses and programs that offered "two or more courses with the word 'evaluation' in the course title" (p. 14). The researchers then gathered detailed information regarding a sample of 120 candidate graduate evaluation programs, including the following: disciplines, types of degrees, and the nature of courses. The searches focused on degree programs only and did not include certificate programs: "the search was linked to pages that contain both a degree (MA or MS or PhD) and the term 'program evaluation"' (p. 13).

Through this search, LaVelle and Donaldson (2010) confirmed 48 programs of study that fit their criteria. Over half (25) of the "sites" offered specialization in evaluation at both the master's and doctoral levels, while 12 offered specialization only in the master's degree and 16 in the doctoral degree only. Their findings of 48 programs represented $26 \%$ more programs than the 38 identified by Altschuld et al. (1994), and 65.5\% more programs than the 29 identified by Engle et al. (2006). LaVelle and Donaldson (2010) determined that 29 programs (60.4\%) were located in schools of education, seven (14.5\%) in educational psychology, five $(10.5 \%)$ in psychology, four in public policy $(8.3 \%)$, and one $(2 \%)$ in each of criminal justice, applied sociology, and interdisciplinary studies. This finding indicated that $85.4 \%$ of programs were located in schools of education, educational psychology, and psychology and was consistent with earlier findings by May et al. (1986), but not Altschuld et al. (1994) or Engle et al. (2006), who respectively found $67 \%$ and $62.1 \%$ of programs located in these three disciplines. With regard to the size of the 48 programs identified by LaVelle and Donaldson (2010), 31 were small (2-3 courses), 14 were medium-sized (4-6 courses), and three were large (7+ courses) programs. LaVelle and Donaldson (2010) noted that they identified 
almost twice as many medium- to large-sized programs and twice as many smallsized programs than Engle et al. (2006). However, the proportion of programs was more in keeping with Engle et al. (2006) than with Altschuld et al. (1994), who found more large programs ( $42.9 \%$ of their sample) and far fewer small programs (30.6\% of their sample).

An apparent limitation of LaVelle and Donaldson's (2010) methodology was focusing their online search on courses with "evaluation" in the title, thus eliminating other courses that may have emphasized evaluation in the content but did not contain the word itself in their titles. In previous studies, Altschuld et al. (1994) found that just over half of the 38 programs (not courses) had "evaluation" in the title, while Engle et al. (2006) indicated that $69 \%$ of the 29 programs they identified used that word in the program titles.

In his dissertation, LaVelle (2014) used the same internet search methodology as he and Donaldson (2010) had used in their earlier study to identify graduate evaluation education programs in the United States. In addition, he analyzed the extent to which curricula were meeting job demands. LaVelle (2014) identified 87 postsecondary institution "sites" in the United States offering graduate evaluation programs with two or more courses with "evaluation" in their titles, including 55 master's degrees, 44 doctoral degrees, four specialist degrees, and 36 graduate certificate programs.

LaVelle's (2014) finding of 87 "sites" in the United States offering an estimated 139 evaluation education programs appears to represent 91 more programs in the United States than the 48 identified by LaVelle \& Donaldson in 2010 (almost three times as many). In his study, LaVelle (2014) included 36 graduate certificate programs, whereas the 2010 study did not include any certificates. In addition, LaVelle (2014) identified 15 international evaluation education programs, of which six were in Canada, including three certificate programs (offered by the University of Victoria, the University of Ottawa, and Carleton University).

LaVelle (2018) produced an updated directory of evaluation education programs offered in the United States, based on online searches and analysis of publicly available course information undertaken in 2017. The 2018 directory included 71 master's and doctoral programs and 42 certificate programs. The 113 programs identified is less than the 139 located earlier (LaVelle, 2014). This directory is not intended to be "definitive," as it may not include all possible evaluation education programs in the United States. The directory will be corrected as needed and updated every four years. It does not provide analysis regarding the size of programs or their discipline locations.

Survey and internet search methodologies both have strengths and limitations. The survey-only approach requires the predetermination of candidate programs and contacts and relies on respondents to return surveys and provide reliable information. Internet-only searches are limited by the degree to which institutional websites are kept up-to-date and contain accurate information about courses and programs. Using these two methods in combination improves the accuracy of data collection. 


\section{INVENTORY OF CANADIAN GRADUATE EVALUATION EDUCATION}

The current study used the same definition of "program" of study in evaluation as was used in previous studies (Altschuld et al., 1994; Engle et al., 2006; LaVelle \& Donaldson, 2010) to identify departmental units offering two or more courses, seminars or practica with an emphasis in program evaluation.

\section{Sampling Frame}

The sampling frame for this Canadian study was constructed on the basis of several leads, including:

- Current members of the Consortium of Universities for Evaluation Education (CUEE)

- CUEE archival lists of courses and potential member programs

- Canadian Evaluation Society (2001), Post-Secondary Evaluation-Related Courses

- Treasury Board of Canada Secretariat (2010), Appendix A-Evaluation Training Program Descriptions

- Devine and McDavid (2009), CUEE Project: Research on Evaluation Education at the Graduate Level in Canadian Universities, Final Report

- Public Health Agency of Canada (n.d.), Educational Programs in Public Health

- universitystudy.ca website, using search term "evaluation"

- ReQUE: Réseau québécois des universitaires en évaluation (2013), Inventaire des cours et formations en évaluation de programme

- Internet [Google] search terms: "graduate 'program evaluation' course Canada"

- Searches of individual university websites using search terms "evaluation courses," as well as manual scans of potentially relevant programs

- Intensive, online searches of Canadian university websites between the fall of 2017 and spring of 2018, to identify/confirm graduate evaluationrelated courses and programs

- Examination of individual university departmental websites and related graduate course calendars to identify additional courses with emphasis in program evaluation.

The initial sample included 316 candidate courses (both single and multiple course offerings) in 105 academic departments located at 35 universities in nine provinces. Key contacts were identified for each department, including directors, deans, graduate program secretaries, and/or faculty/instructors of evaluation courses.

\section{Data Collection}

Initial lists of graduate evaluation courses were compiled for each department and university and then grouped by province and saved as individual pdf documents. 
The tentative lists of courses and programs were sent to identified key contacts with a cover email (in either French or English, as applicable) that provided information about the 2018 Evaluation Education Inventory Project and asked them to voluntarily participate in the study. Departmental representatives were asked to verify whether the courses listed were currently being offered and had a major emphasis on program evaluation and to update and make corrections to course numbers, titles, and brief course descriptions. Contacts were also invited to provide information regarding additional graduate courses with a major emphasis on program evaluation offered by their departments.

\section{Response Rate}

The overall response rate for 129 departments located at 35 universities was $57 \%$ and was similar between predominantly English- and French-speaking universities. Initial lists of courses were revised based on feedback and input received from key contacts. For those courses that were not verified by contacts, additional online searches were conducted to validate that they were currently listed on departmental websites and linked to current and/or future years' graduate course calendars.

\section{Analysis}

Penultimate lists of validated evaluation courses were reviewed by two members of the research team (in French and/or English, as applicable) to ensure that all course titles and brief descriptions met the criteria for inclusion in the inventory. These courses covered a wide range of disciplines and subject areas, including economic evaluation and policy development and performance evaluation, with emphasis on program evaluation.

The validated lists of courses were divided into those departments that offered single courses and those that offered two or more courses and therefore qualified as "programs." Departments that offered programs of study in program evaluation were included in the final inventory. Single-course offerings were tracked separately, since they provide an important indication that students are being exposed to "evaluation concepts and processes" (LaVelle \& Donaldson, 2010, p. 19).

\section{RESULTS}

The complete list of universities, departments, and course titles of the $2018 \mathrm{Ca}$ nadian Inventory of Graduate Evaluation Education Programs is presented in the Appendix. As shown in Table 1, our study confirmed 239 graduate courses (including some methodology courses) with emphasis in evaluation offered in programs of study (two or more courses) by 54 departments at 27 universities in eight Canadian provinces.

\section{Program Size}

In keeping with previous studies (Engle et al., 2006; LaVelle \& Donaldson, 2010), the number of courses offered by departments was ranked to determine the size of 
Table 1. Number of universities, departments, and courses by province

\begin{tabular}{lccc}
\hline Province & Universities & Departments & \# Courses \\
\hline British Columbia & 3 & 3 & 16 \\
Alberta & 2 & 4 & 11 \\
Saskatchewan & 2 & 4 & 18 \\
Manitoba & 2 & 3 & 8 \\
Ontario & 8 & 14 & 73 \\
Quebec & 7 & 20 & 88 \\
Nova Scotia & 2 & 2 & 7 \\
Newfoundland and Labrador & 1 & 4 & 18 \\
Total & 27 & 54 & 239 \\
\hline
\end{tabular}

Table 2. Number of courses offered by Canadian university departments

\begin{tabular}{lcc}
\hline \# courses & \# departments & Total \# of courses \\
\hline 2 & 13 & 26 \\
3 & 12 & 36 \\
4 & 10 & 40 \\
5 & 5 & 25 \\
6 & 4 & 24 \\
7 & 3 & 21 \\
8 & 3 & 24 \\
9 & 3 & 27 \\
16 & 1 & 16 \\
Total & 54 & 239 \\
\hline
\end{tabular}

programs. This proxy measure provides a rough indication of how much emphasis is given to evaluation within graduate programs. Table 2 presents the number of evaluation courses offered by 54 departments at Canadian universities, including 25 small programs (2-3 evaluation courses) (44\%), 19 medium-sized programs (4-6 courses) (37\%), and 10 large programs ( 7 or more courses) (19\%).

Table 3 identifies the departments, institutions, and locations of the 10 large evaluation education programs, including two in Quebec, five in Ontario, one in British Columbia, one in Saskatchewan, and one in Newfoundland and Labrador.

\section{Range of Disciplines Offering Programs of Study in Evaluation}

The current study identified evaluation education programs in 15 different disciplines, as shown in Table 4 . The most common types of schools were medicine (9; 17\%), education/educational psychology $(9 ; 17 \%)$, health-related disciplines (7; 13\%), public policy and administration $(6 ; 11 \%)$, management studies $(4 ; 7 \%)$, social work (4; 7\%), and psychology (4; 7\%). 
Table 3. Details regarding large evaluation education programs in Canada

\begin{tabular}{|c|c|c|}
\hline University & Department & \# of Courses \\
\hline $\begin{array}{l}\text { 1. Université du Québec, École } \\
\text { nationale d'administration } \\
\text { publique (ENAP) Québec }\end{array}$ & $\begin{array}{l}\text { École nationale d'administration } \\
\text { publique }\end{array}$ & 16 \\
\hline 2. University of Toronto Ontario & $\begin{array}{l}\text { Institute of Health Policy, Man- } \\
\text { agement and Evaluation }\end{array}$ & 9 \\
\hline 3. University of Ottawa Ontario & $\begin{array}{l}\text { École de gestion Telfer / Telfer } \\
\text { School of Management }\end{array}$ & 9 \\
\hline $\begin{array}{l}\text { 4. University of Waterloo } \\
\text { Ontario }\end{array}$ & $\begin{array}{l}\text { School of Public Health and } \\
\text { Health Systems }\end{array}$ & 9 \\
\hline 5. University of Ottawa Ontario & $\begin{array}{l}\text { Faculty of Education, and Faculty } \\
\text { of Social Sciences, School of } \\
\text { Psychology }\end{array}$ & 8 \\
\hline 6. Carleton University Ontario & $\begin{array}{l}\text { School of Public Policy and } \\
\text { Administration }\end{array}$ & 8 \\
\hline $\begin{array}{l}\text { 7. Université du Québec à } \\
\text { Montréal Québec }\end{array}$ & École des sciences de la gestion & 8 \\
\hline $\begin{array}{l}\text { 8. University of Victoria British } \\
\text { Columbia }\end{array}$ & School of Public Administration & 7 \\
\hline $\begin{array}{l}\text { 9. University of Regina Sas- } \\
\text { katchewan }\end{array}$ & $\begin{array}{l}\text { Johnson-Shoyama Graduate } \\
\text { School of Public Policy }\end{array}$ & 7 \\
\hline $\begin{array}{l}\text { 10. Memorial University New- } \\
\text { foundland and Labrador }\end{array}$ & $\begin{array}{l}\text { Faculty of Medicine, Graduate } \\
\text { Studies in Medicine }\end{array}$ & 7 \\
\hline
\end{tabular}

Table 4. Academic disciplines offering programs of study in evaluation in Canada

\begin{tabular}{lcc}
\hline Discipline & No. depts. & $\%$ \\
\hline Medicine & 9 & $17 \%$ \\
Education / Educational psychology & 9 & $17 \%$ \\
Health & 7 & $13 \%$ \\
Public policy / Administration & 6 & $11 \%$ \\
Management & 4 & $7 \%$ \\
Social work & 4 & $7 \%$ \\
Psychology & 4 & $7 \%$ \\
Continuing education & 2 & $4 \%$ \\
Graduate studies & 2 & $4 \%$ \\
Political science & 2 & $4 \%$ \\
Economics & 1 & $2 \%$ \\
Environmental design & 1 & $2 \%$ \\
International affairs & 1 & $2 \%$ \\
Pharmacy & 1 & $2 \%$ \\
Industrial relations & 1 & \\
\hline
\end{tabular}


The findings of this study can be compared with the results of American research on evaluation education programs. We found only $21 \%$ of evaluation education programs in departments of education, educational psychology, and psychology, whereas May et al. (1986) and LaVelle and Donaldson (2010) found $85 \%$, Altschuld et al. (1994) identified 67\%, Engle et al. (2006) reported 62.1\%, and LaVelle (2014) noted that $79.5 \%$ of programs offering specialization in evaluation were located in these three disciplines.

Our study found a greater number and more diverse range of 15 different academic disciplines offering evaluation education programs at Canadian universities compared with studies of programs offered at universities in the United States. Including the top three disciplines offering evaluation education programs (education, educational psychology, and psychology) LaVelle and Donaldson (2010) identified a total of seven different disciplines (with the addition of public policy, criminal justice, applied sociology, and interdisciplinary studies), while LaVelle (2014) found eight (with the addition of public policy, public health, sociology, social work, and business).

\section{Graduate Degrees with Specialization in Evaluation}

Our study identified a range of graduate degrees offered by departments with evaluation education courses:

- $\quad$ Most offered degrees at the master's level (e.g., MA, MPA, MPH, MSc)

- 22 departments (41\%) offered PhDs;

- $\quad$ Six (11\%) offered graduate certificate / diploma programs in evaluation

- Several others offered diploma programs with various specializations (e.g., community health sciences, public policy and administration, public administration)

- Quebec universities frequently offered short, graduate-level microprograms that vary in the number of required courses and credit hours ${ }^{1}$

It is not possible to directly compare these findings with studies of evaluation programs in the United States. Engle et al. (2006) found more doctoral programs among the 24 American universities offering specialization in evaluation, with 15 PhDs (62.5\%) and 6 EdDs (25\%), as well as 15 programs offering MA/MS (62.5\%), 6 graduate certificates (25\%), and one non-degree program. LaVelle and Donaldson (2010) found over half (52.1\%) of the 48 programs offering evaluation education programs were offered for both the master's and doctoral degrees, 12 (18.7\%) were offered in master's degree programs only, and 16 (29.2\%) were offered in doctoral programs only (this study did not consider certificate programs). Of the 87 postsecondary institutions offering graduate evaluation programs identified by LaVelle (2014), the majority were offered in master's and doctoral degrees, as well as 37 graduate certificate programs. LaVelle's (2018) directory of graduate evaluation education programs included 71 master's and doctoral degrees and 42 certificates 
offered by universities in the United States. There appears to be substantial growth in certificate programs in the United States offering evaluation education.

\section{Canadian Graduate Certificate and Diploma Programs in Evaluation}

Six Canadian universities offer specialized graduate certificate and diploma programs in evaluation. As shown in Table 5, three of these programs have been in place since the mid-2000s. Three are located in schools of public policy and administration, one is a joint program in education and psychology, one is in management studies, and one is offered by graduate studies. Three of these programs are available online and three provide options to study in French.

\section{Single Course Offerings}

In addition to the evaluation programs identified, our study found 61 departments that offer single courses in evaluation within graduate degree programs. As noted, single courses indicate that students are receiving some information about program evaluation concepts and methods (LaVelle \& Donaldson, 2010). The large number of departments offering single courses in evaluation suggests acknowledgment of the relevance of program evaluation across a wide range of disciplines. Some professional associations now have requirements for program evaluation to be included in curricula, such as the Canadian Psychological Association (2011) standards for accreditation of doctoral programs in clinical neuropsychology and clinical, counselling, and school psychology. This indicates a growing recognition of the usefulness of program evaluation in applied settings that may underlie the large number of single courses with emphasis in evaluation across various disciplines.

\section{DISCUSSION}

This is the first empirical study to develop a comprehensive inventory of graduate evaluation education programs in Canada. Previous efforts to identify and compile lists of courses and programs in Canada (CES, 2001; Devine \& McDavid, 2009; Treasury Board of Canada Secretariat, 2010) were used to develop the sampling frame for the current study. The ReQUE (2013) Project Report was the most comprehensive listing of evaluation education courses offered by universities in Quebec.

This study identified 54 graduate programs of study offering two or more courses with emphasis in evaluation, with a total of 239 courses at 27 Canadian universities. These programs were offered by 15 different disciplines across all universities. Over half (57\%) of the departments that were contacted validated that the courses were currently offered and provided input that ensured they were accurately described. The remaining courses were validated through intensive online searches of university departmental and graduate calendars to confirm they were current and being offered.

Our results indicate that Canada has about half the number of evaluation education programs compared with the most recent findings regarding programs 
Table 5. Graduate certificate and diploma credential programs in evaluation

\begin{tabular}{|c|c|c|c|c|}
\hline $\begin{array}{l}\text { Date of } \\
\text { origin }\end{array}$ & Institution & Department & Delivery & Credential \\
\hline $\begin{array}{l}2006 \text { on- } \\
\text { campus } \\
2016 \text { online }\end{array}$ & $\begin{array}{l}\text { Carleton } \\
\text { University }\end{array}$ & $\begin{array}{l}\text { School of Public } \\
\text { Policy and } \\
\text { Administration }\end{array}$ & $\begin{array}{l}\text { Online } \\
\text { English }\end{array}$ & $\begin{array}{l}\text { Graduate Diploma } \\
\text { in Public Policy } \\
\text { and Program } \\
\text { Evaluation }\end{array}$ \\
\hline 2006 & $\begin{array}{l}\text { University of } \\
\text { Ottawa }\end{array}$ & $\begin{array}{l}\text { Faculty of Education, } \\
\text { and Faculty of } \\
\text { Social Sciences, } \\
\text { School of } \\
\text { Psychology }\end{array}$ & $\begin{array}{l}\text { On-campus } \\
\text { French and } \\
\text { English }\end{array}$ & $\begin{array}{l}\text { Graduate Diploma } \\
\text { in Program } \\
\text { Evaluation } \\
\text { / Diplôme } \\
\text { d'études } \\
\text { supérieures } \\
\text { en évaluation } \\
\text { et gestion du } \\
\text { risque santé des } \\
\text { populations }\end{array}$ \\
\hline 2010 & $\begin{array}{l}\text { University of } \\
\text { Victoria }\end{array}$ & $\begin{array}{l}\text { School of Public } \\
\text { Administration }\end{array}$ & $\begin{array}{l}\text { Online } \\
\text { English }\end{array}$ & $\begin{array}{l}\text { Graduate } \\
\text { Certificate and } \\
\text { Diploma in } \\
\text { Evaluation }\end{array}$ \\
\hline 2018 & $\begin{array}{l}\text { University of } \\
\text { the Fraser } \\
\text { Valley }\end{array}$ & $\begin{array}{l}\text { School of Graduate } \\
\text { Studies }\end{array}$ & $\begin{array}{l}\text { Online } \\
\text { English }\end{array}$ & $\begin{array}{l}\text { Graduate } \\
\text { Certificate } \\
\text { in Program } \\
\text { Evaluation }\end{array}$ \\
\hline 2013 & $\begin{array}{l}\text { Université du } \\
\text { Québec à } \\
\text { Montréal } \\
\text { (UQÀM) }\end{array}$ & $\begin{array}{l}\text { École des sciences de } \\
\text { la gestion } \\
\text { [School of } \\
\text { Management } \\
\text { Sciences] }\end{array}$ & $\begin{array}{l}\text { On-campus } \\
\text { French }\end{array}$ & $\begin{array}{l}\text { Diplôme d'études } \\
\text { supérieures } \\
\text { spécialisées } \\
\text { (DEES) en } \\
\text { évaluation de } \\
\text { programmes, } \\
\text { projets et } \\
\text { services }\end{array}$ \\
\hline pre-2008 & $\begin{array}{l}\text { Université du } \\
\text { Québec }\end{array}$ & $\begin{array}{l}\text { École nationale } \\
\text { d'administration } \\
\text { publique (ÉNAP) }\end{array}$ & $\begin{array}{l}\text { On-campus, } \\
\text { some } \\
\text { courses } \\
\text { available } \\
\text { online } \\
\text { French and } \\
\text { English }\end{array}$ & $\begin{array}{l}\text { Graduate Diploma } \\
\text { in Program } \\
\text { Evaluation / } \\
\text { Diplôme } \\
\text { d'études } \\
\text { supérieures } \\
\text { spécialisées } \\
\text { (DEES), } \\
\text { Concentration } \\
\text { en évaluation de } \\
\text { programmes }\end{array}$ \\
\hline
\end{tabular}


located in the United States (LaVelle, 2018); however, Canada has proportionately more programs when the population size of the two countries is taken into account. In 2018, our study identified three times more large graduate programs of study with emphasis in evaluation than were found in the United States in 2008 (10; 19\% vs. 3; 6\%) (LaVelle \& Donaldson, 2010). Canada also has a more diverse range of disciplines offering evaluation education programs, compared with inventories of American evaluation education programs, where the vast majority were in schools of education, educational psychology, and psychology. The most common programs of study in evaluation at Canadian universities in 2018 were located in faculties of medicine, departments of health disciplines, and schools of public policy and administration.

Specialized graduate certificate/diploma programs in evaluation are offered by six different Canadian universities, with three in public policy and administration, one joint program in education and psychology, one in graduate studies, and one in management sciences. Three of these credential programs have existed since the mid-2000s, and three emerged more recently. The number of certificate programs offering evaluation education in the United States appears to be expanding, from six in 2000-2002, initially identified by Engle et al. (2006), to 36 in 2011-2012, noted by LaVelle (2014), and 42 in 2017, reported by LaVelle (2018).

Over the years, the field of evaluation has grown and diversified and become increasingly professionalized. Since 1981, the Canadian Evaluation Society has taken a number of innovative steps to support the professionalization of evaluation in Canada. Requirements to evaluate government programs (Treasury Board, 2016) have increased the demand for qualifications to undertake this work. University partners, such as the CUEE, have sought to build capacity and expand university evaluation education. Graduate evaluation education is now offered by a wide range of departments among Canadian universities, and the number of evaluation courses has expanded, compared to previous listings (Devine \& $\mathrm{McDa}$ vid, 2009; Engle et al., 2006). This indicates a growing awareness of the relevance of evaluation across disciplines.

Constructing inventories is challenging in part because of a tendency for methodologies to yield results that undercount courses, programs, and institutions. By starting with a previously identified population of programs as the basis of the sampling frame, there is the risk of missing programs. Comparisons across countries or over time are subject to this general problem of missing data. Even by using intensive internet searches and following up with surveys of pre-identified programs, there is no assurance that the 2018 Inventory includes all possible programs or evaluation courses in Canada.

The 2018 Canadian Inventory of Graduate Evaluation Education is a resource for CUEE members and other stakeholders with an interest in graduate evaluation education. The inventory will also be of interest to professional associations and governments as they seek to expand the knowledge and skills of evaluators. Finally, the 2018 Inventory will act as a baseline for future studies and ongoing monitoring of graduate evaluation education in Canada. 


\section{NOTE}

1 Examples of micrioprograms: Laval: 4 to 6 courses (12 to 18 credits); ÉNAP: 3 courses (9 credits).

\section{REFERENCES}

Altschuld, J. W., Engle, M., Cullen, C., Kim, I., \& Macce, B. R. (1994). The 1994 directory of evaluation training programs. In J. W. Altschuld \& M. Engle (Eds.), The preparation of professional evaluators: Issues, perspectives, and programs. New Directions for Program Evaluation, 1994(62), 71-94. https://doi.org/10.1002/ev.1678

Canadian Evaluation Society (CES). (n.d.). About the CE designation. Retrieved from https://evaluationcanada.ca/ce

Canadian Evaluation Society (CES). (n.d.). Our history. Retrieved from https://evaluation canada.ca/our-history

Canadian Evaluation Society (CES). (2001, June). Post-secondary evaluation-related courses. Unpublished report.

Canadian Evaluation Society (CES). (2010, April 14). Professional designations project (archives). Retrieved from https://evaluationcanada.ca/professional-designationsproject-archives

Canadian Psychological Association (CPA). (2011). Accreditation standards and procedures for doctoral programmes and internships in professional psychology, 5th revision. Ottawa, ON: Author.

Conner, R. F., Clay, T., \& Hill, P. (1980). Directory of evaluation training. Washington, DC: Pintail Press.

Consortium of Universities for Evaluation Education (CUEE). (n.d.). Homepage. Retrieved from http://evaluationeducation.ca/

Devine, H., \& McDavid, J. (2009, June). Consortium of Universities for Evaluation Education (CUEE) project: Research on evaluation education at the graduate level in Canadian universities. Unpublished report.

Engle, M., Altschuld, J. W., \& Kim, Y.-C. (2006). 2002 Survey of evaluation preparation programs in universities: An update of the 1992 American Evaluation Association-sponsored study. American Journal of Evaluation, 27(3), 353-359. https://doi. org/10.1177/1098214006288787

LaVelle, J. M. (2014). An analysis of evaluation education programs and evaluator skills across the world [Doctoral dissertation]. Claremont Graduate University, CA. Retrieved from http://search.proquest.com/docview/1527108167

LaVelle, J. M. (2018). 2018 directory of evaluator education programs in the United States. Minneapolis, MN: University of Minnesota Libraries Publishing.

LaVelle, J. M., \& Donaldson, S. I. (2010). University-based evaluation training programs in the United States 1980-2008: An empirical examination. American Journal of Evaluation, 31(1), 9-23. https://doi.org/10.1177/1098214009356022

LaVelle, J. M., \& Donaldson, S. I. (2015). The state of preparing evaluators. In J. W. Altschuld \& M. Engle (Eds.), Accreditation, certification, and credentialing: Relevant 
concerns for U.S. evaluators. New Directions for Evaluation, 2015(145), 39-52. https:// doi.org/10.1002/ev.20110

May, R. M., Fleischer, M., Scheirer, C. J., \& Cox, G. B. (1986). Directory of evaluation training programs. In B. Gross-Davis (Ed.), Teaching evaluation across the discipline. New Directions for Program Evaluation, 1986(29), 71-98. https://doi.org/10.1002/ev.1421

Public Health Agency of Canada. (n.d.). Educational programs in public health. Retrieved from http://www.phac-aspc.gc.ca/php-psp/master_of_php-eng.php

Réseau québécois des universitaires en évaluation (ReQUE). (2013, May). Inventaire des cours et formations en évaluation de programme. Unpublished report. Retrieved from https://www.sqep.ca/app/uploads/2017/11/Formation_ReQUE.pdf

Stockmann, R., \& Meyer, W. (Eds.). (2016). The future of evaluation (pp. 9-19). London, England: Palgrave Macmillan.

Treasury Board. (2016). Policy on results. Ottawa, ON: Government of Canada. Retrieved from https://tbs-sct.gc.ca/pol/doc-eng.aspx?id=31300

Treasury Board of Canada Secretariat. (2010, February 25). Appendix A-Evaluation training program descriptions. Ottawa, ON: Centre of Excellence for Evaluation (CEE). Retrieved from http://www.tbs-sct.gc.ca/cee/tools-outils/qae-aqe/annexa-eng.asp

universitystudy.ca. (n.d.). Retrieved from http://www.universitystudy.ca/search-programs/

Yarbrough, D. B., Shulha, L. M., Hopson, R. K., \& Caruthers, F. A. (2011). The program evaluation standards: A guide for evaluators and evaluation users ( $3 \mathrm{rd} \mathrm{ed}$.). Thousand Oaks, CA: SAGE.

Worthen, B. (1990). Program evaluation. In H. Walberg \& G. Haertel (Eds.), The international encyclopedia of educational evaluation (pp. 42-47). Toronto, ON: Pergamon Press.

\section{AUTHOR INFORMATION}

M. Theresa Hunter, $\mathrm{PhD}$, is an independent consultant in Victoria, British Columbia. Her research interests include social policy regarding children's rights and early childhood education and care, research ethics, and graduate evaluation education. The research for this publication was conducted as a Consortium of Universities for Evaluation Education (CUEE) project.

James C. McDavid is professor emeritus of public administration at the University of Victoria. His research includes topics in program evaluation, performance measurement, and performance management. He has conducted research and program evaluations focusing on federal, state, provincial, and local governments in the United States and Canada. His publications include articles and books on program evaluation (most recently evaluation education), performance measurement, performance management, and comparisons of local government service performance across Canada. The third edition of his textbook, Program Evaluation and Performance Measurement: An Introduction to Practice, has recently been published by SAGE Publications in 2019. 


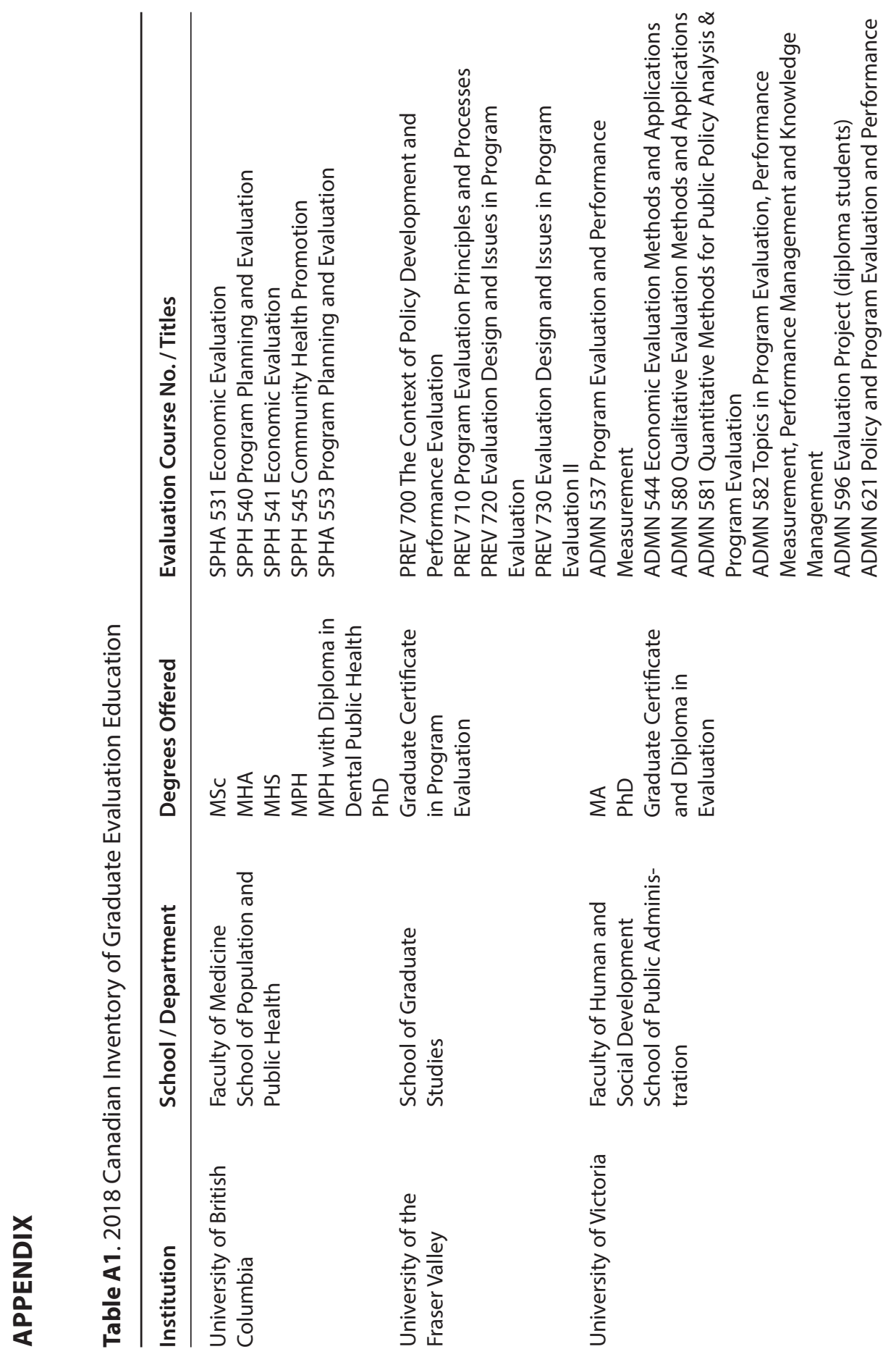



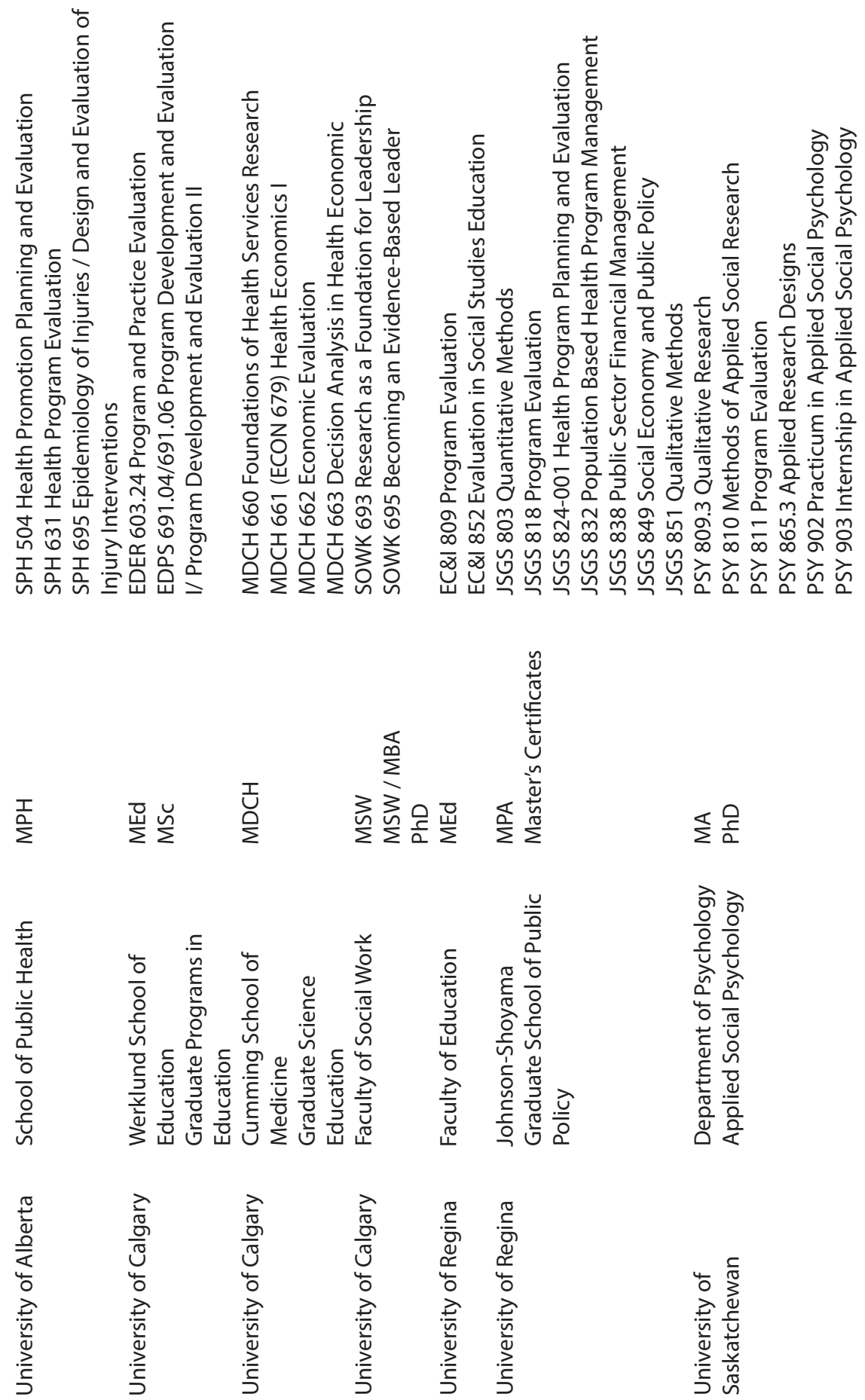


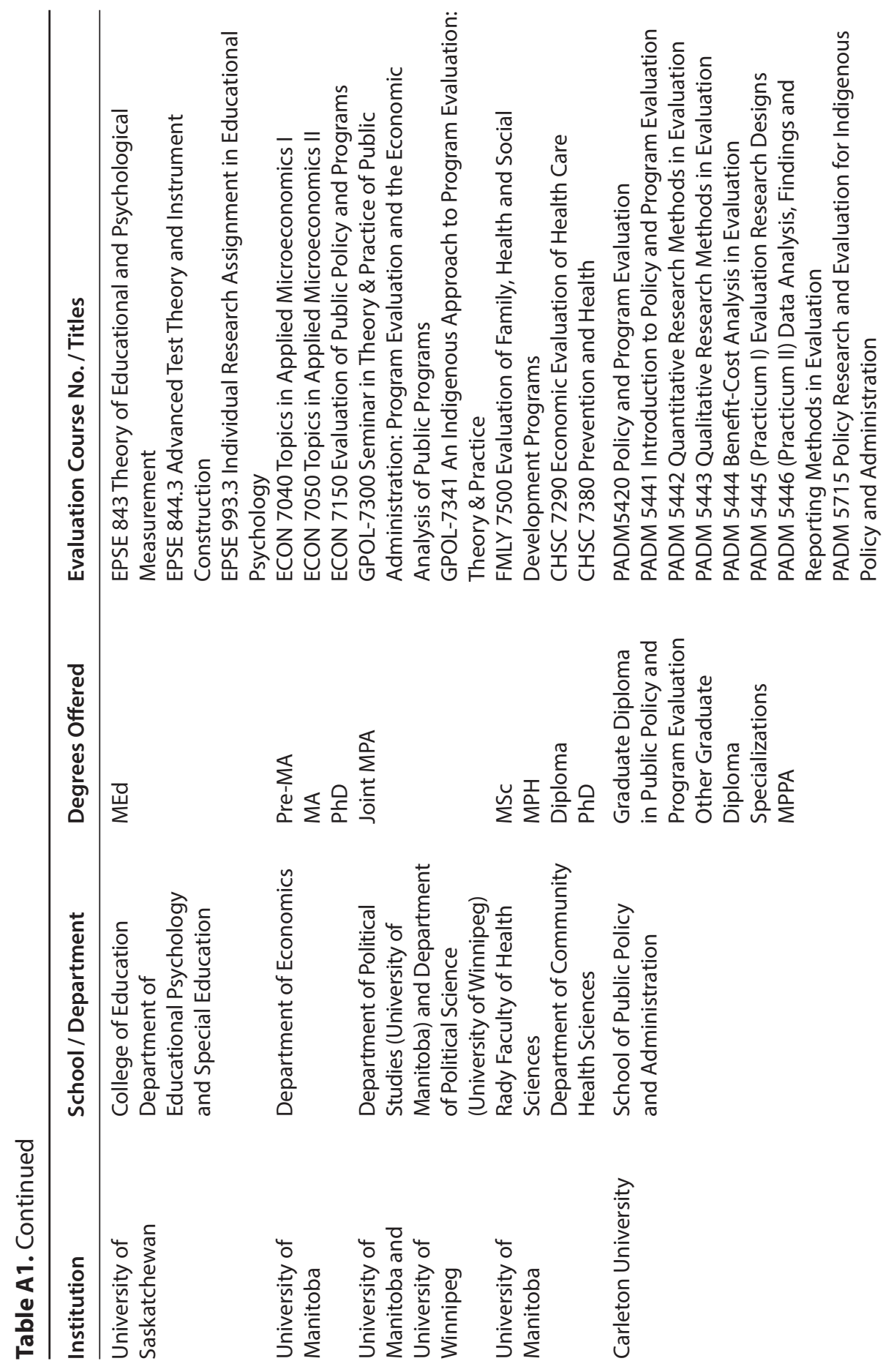




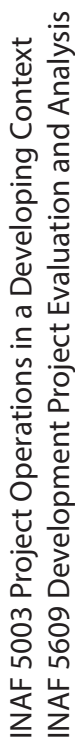

돈

峁焉
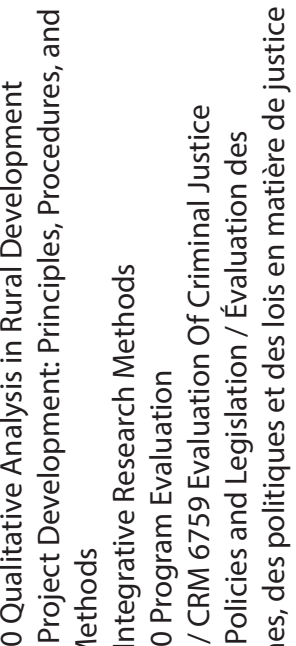

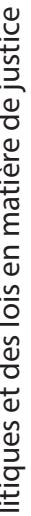

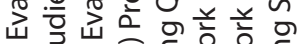

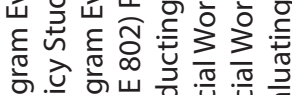

흔 응 융

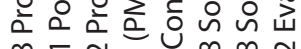

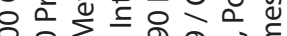

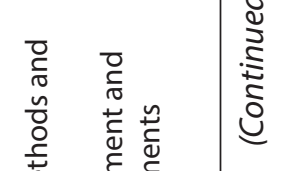

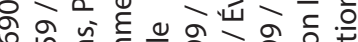

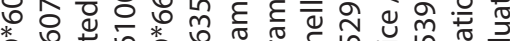

*

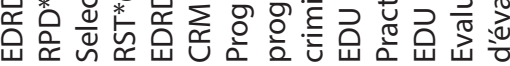

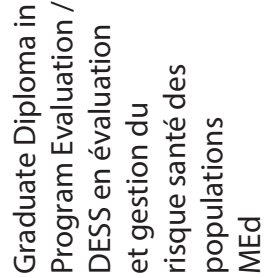

$\sum \frac{0}{2} \quad \frac{0}{\frac{0}{2}}$
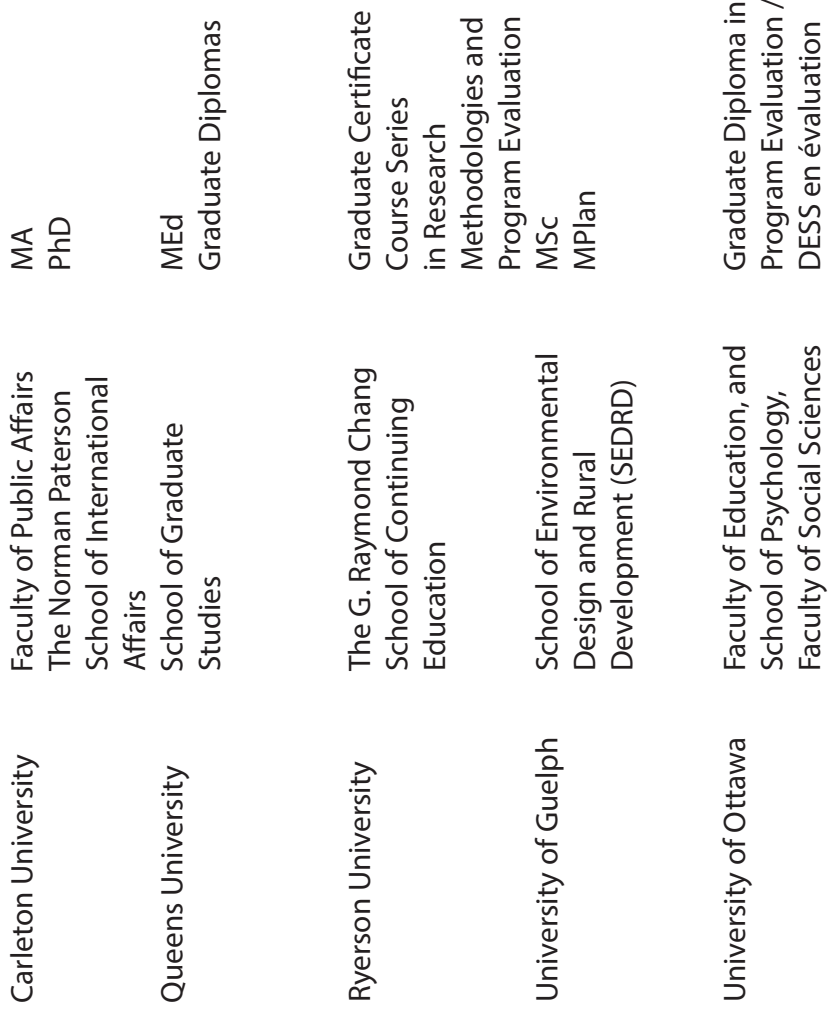

水 


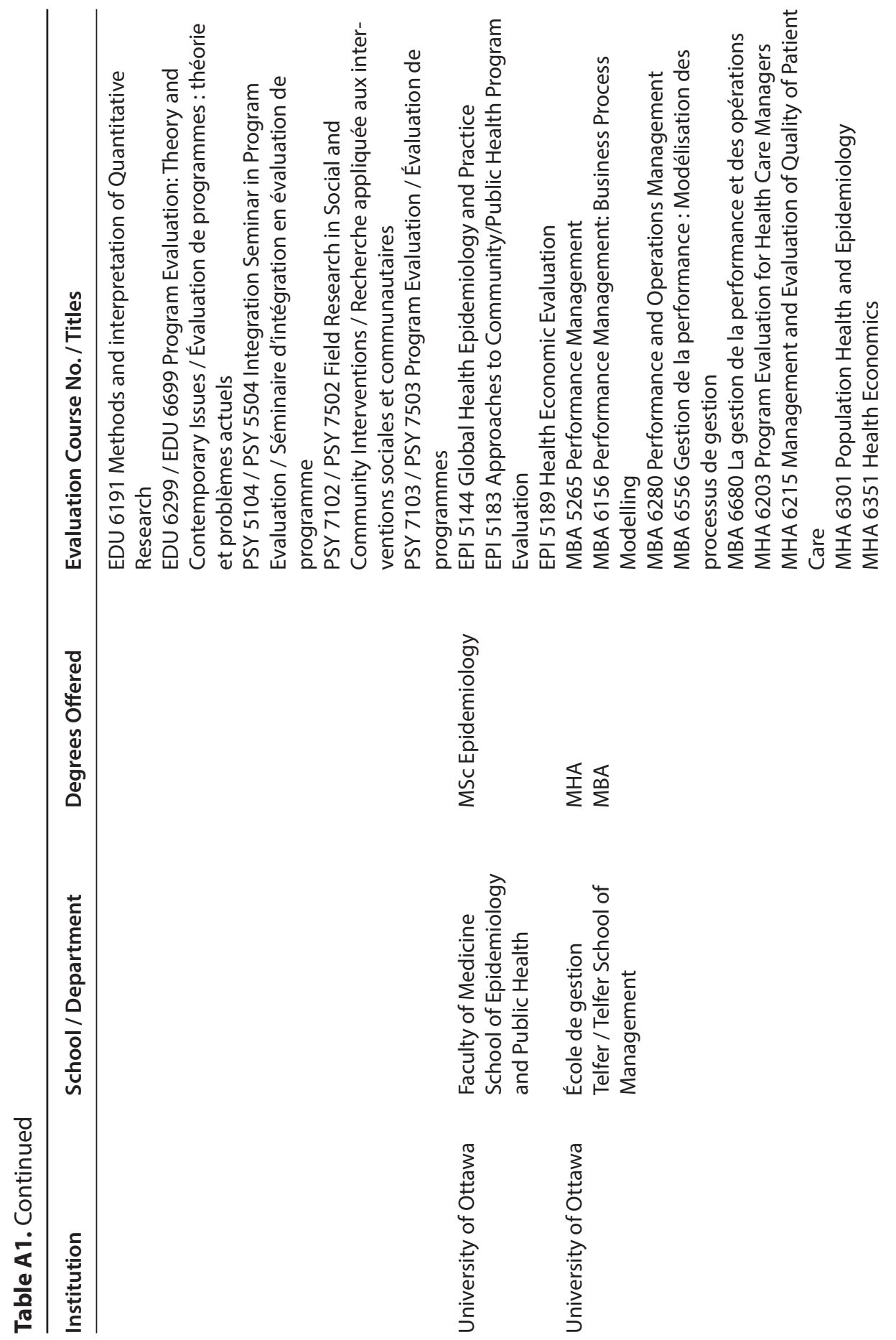



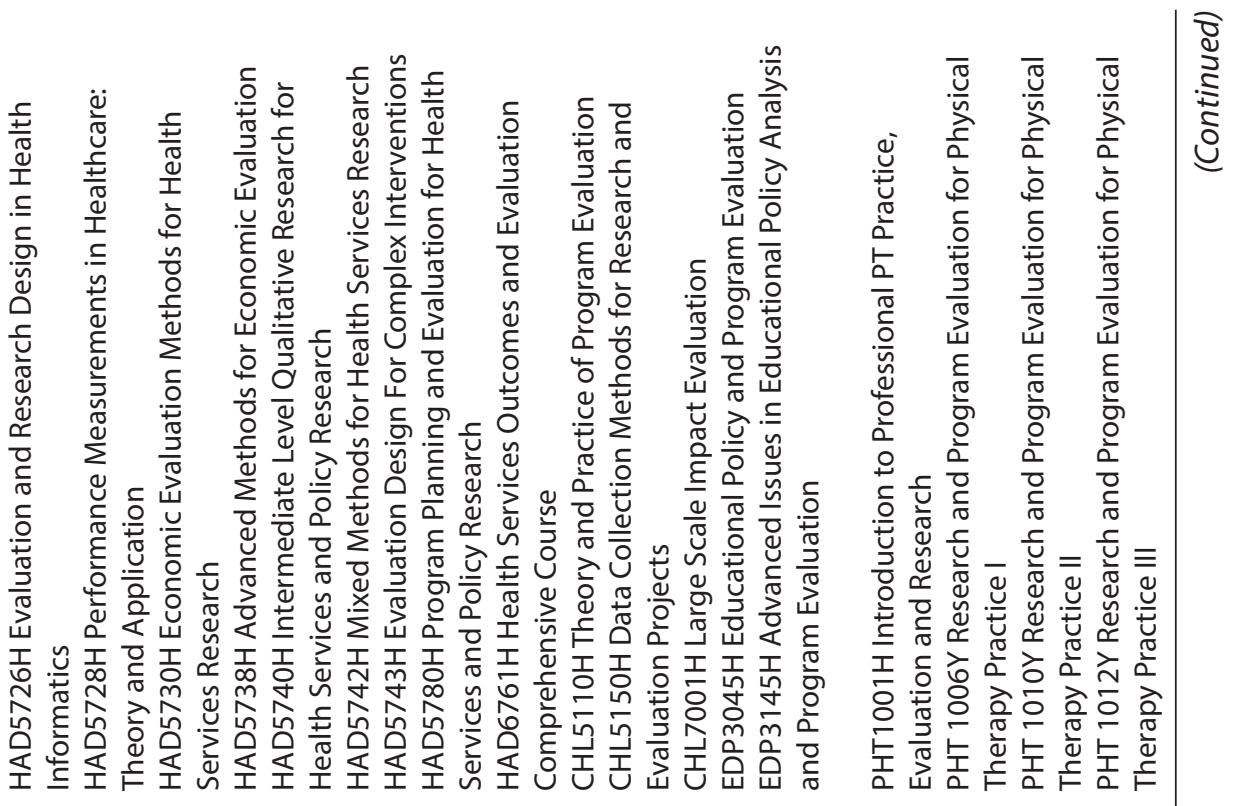

㞮을
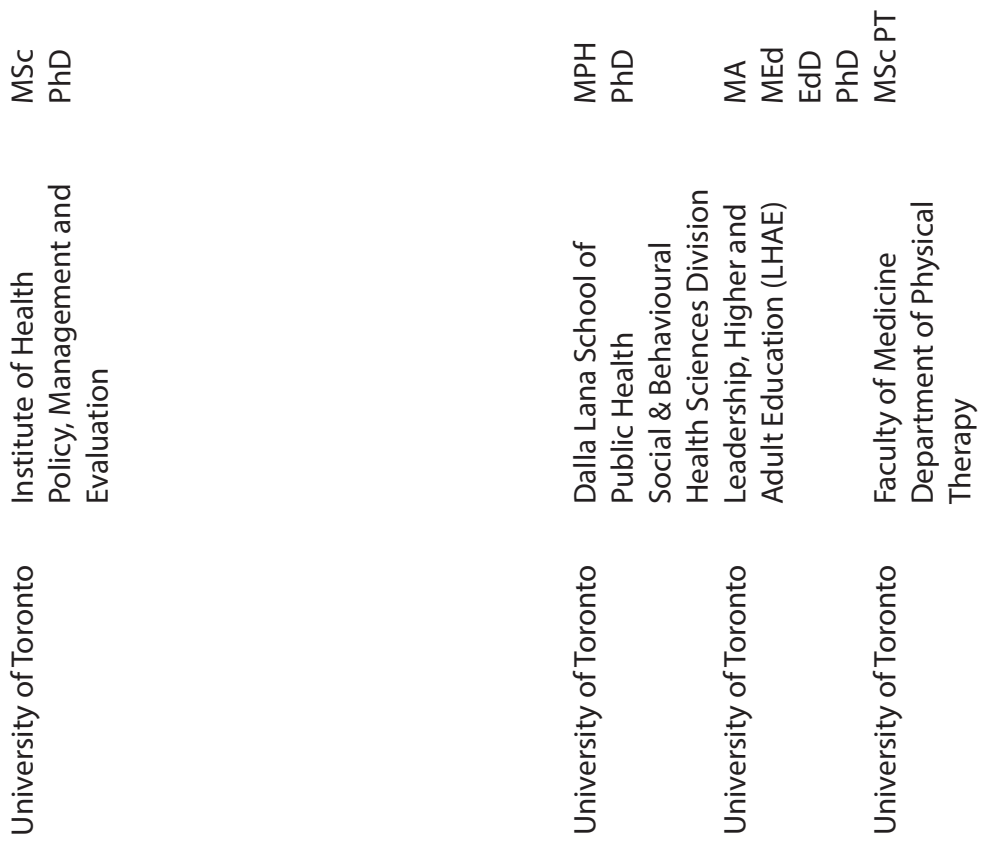


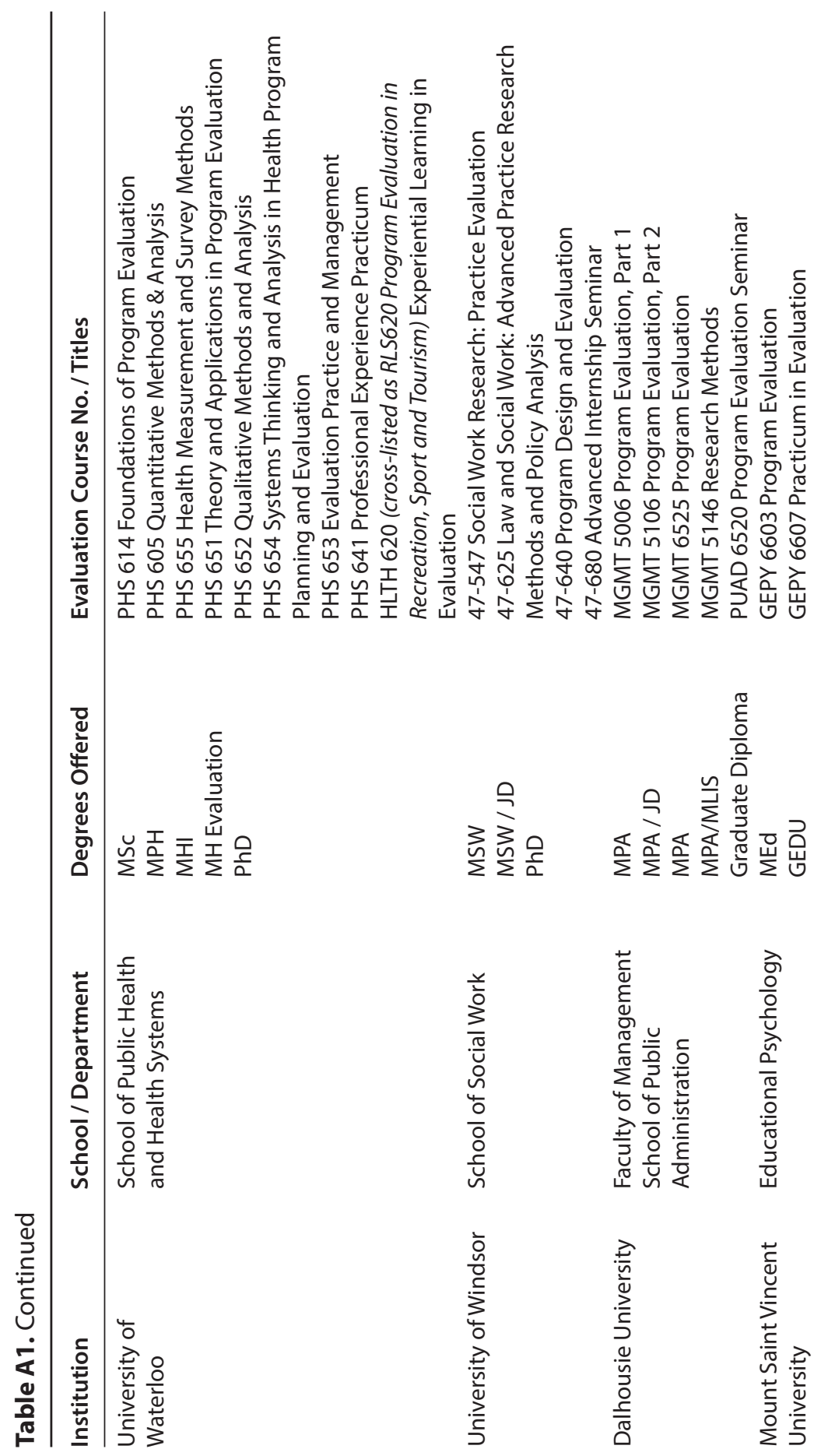



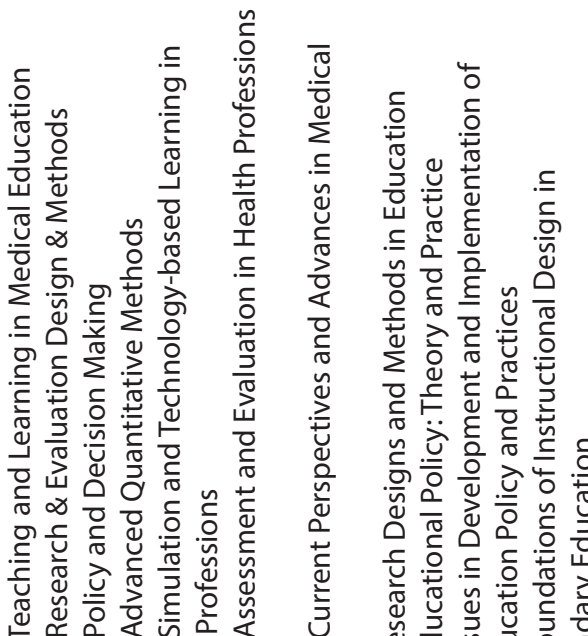

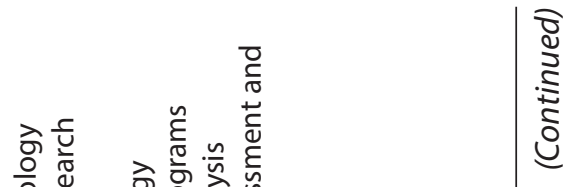

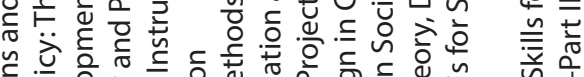

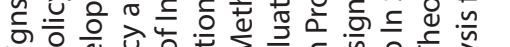

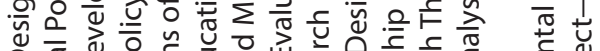

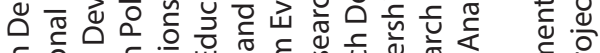

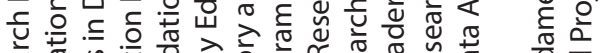

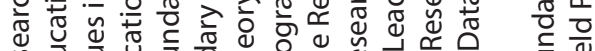

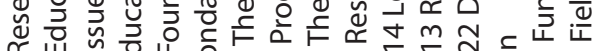

○

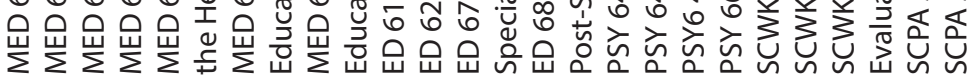

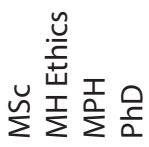

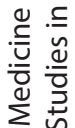

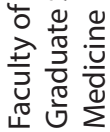

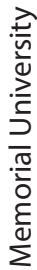

异

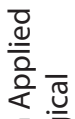

$\subseteq \frac{0}{\circ}$

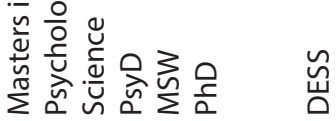

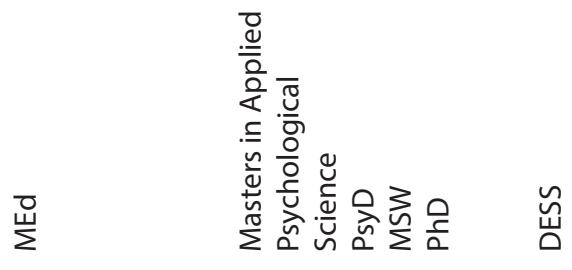

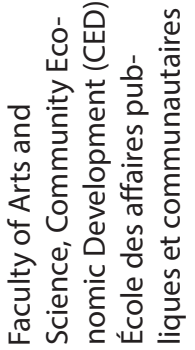

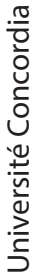




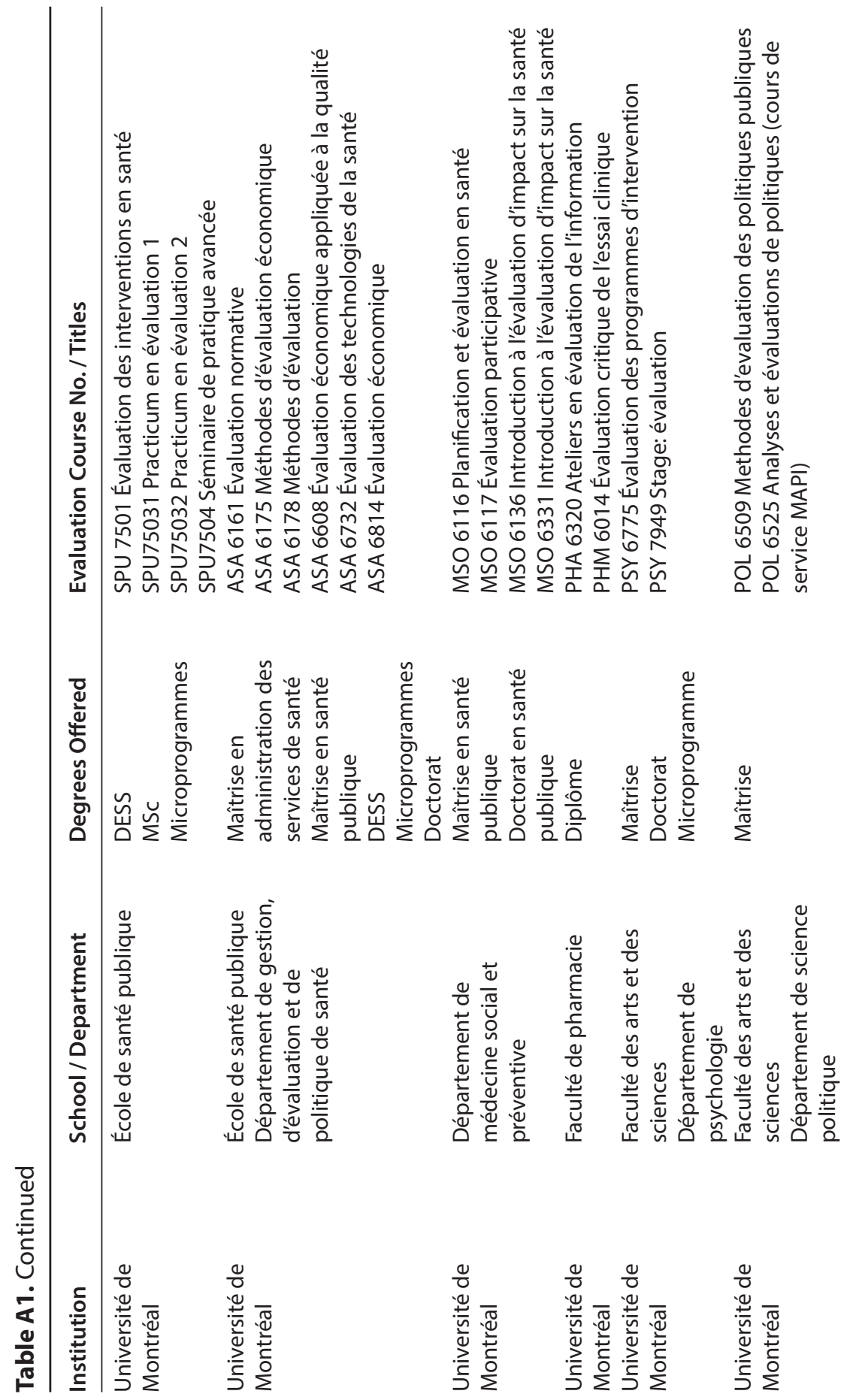



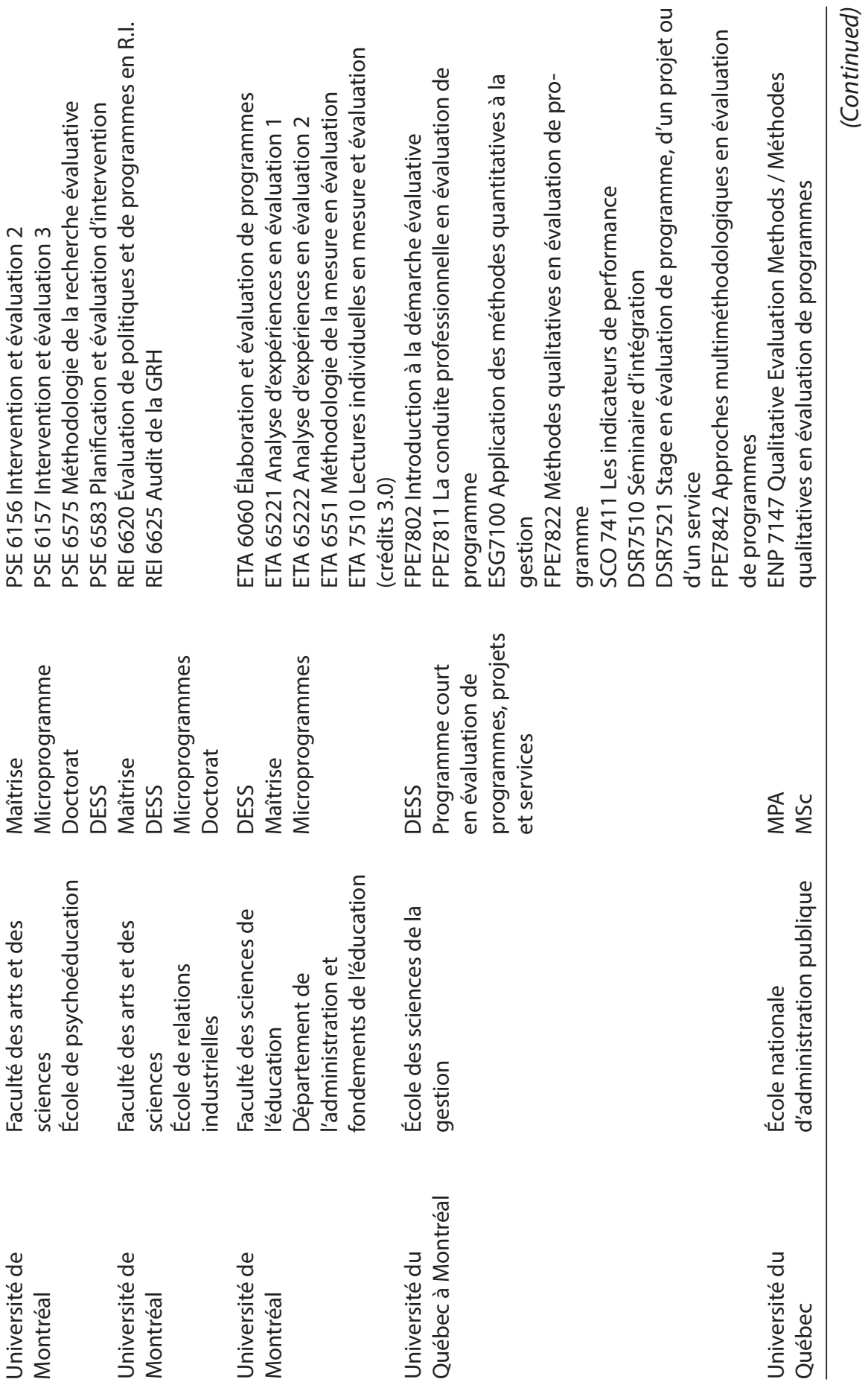


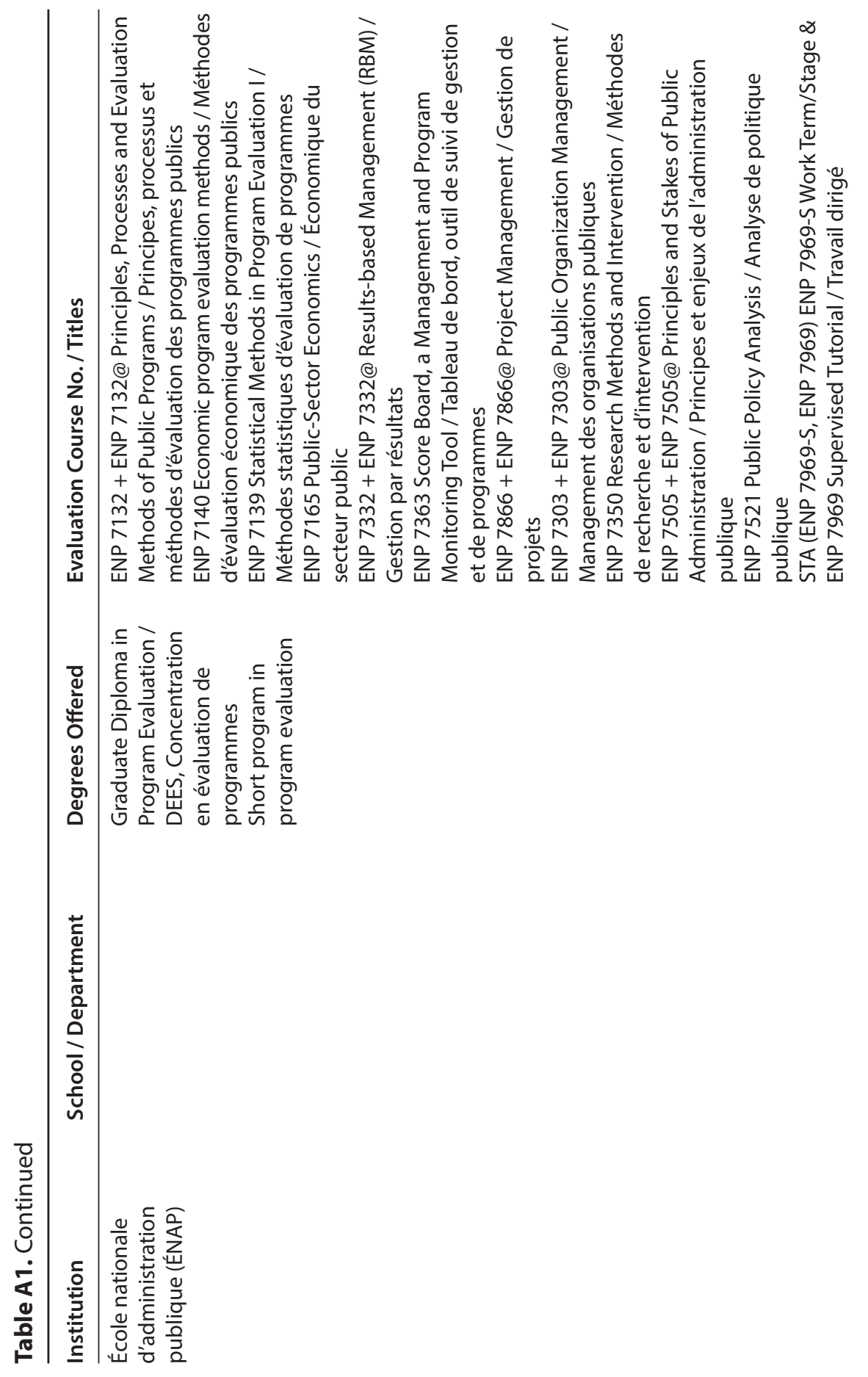



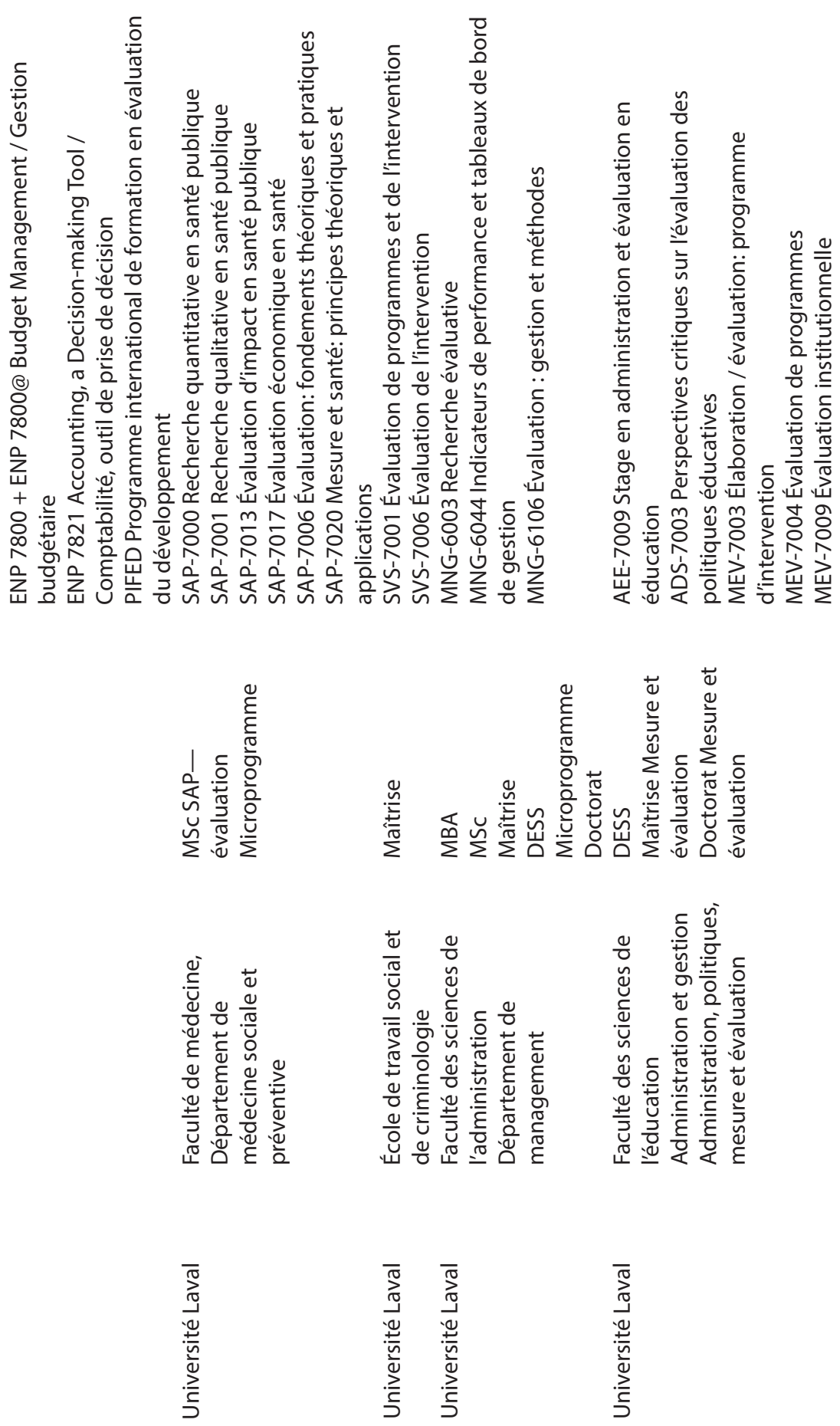

范 


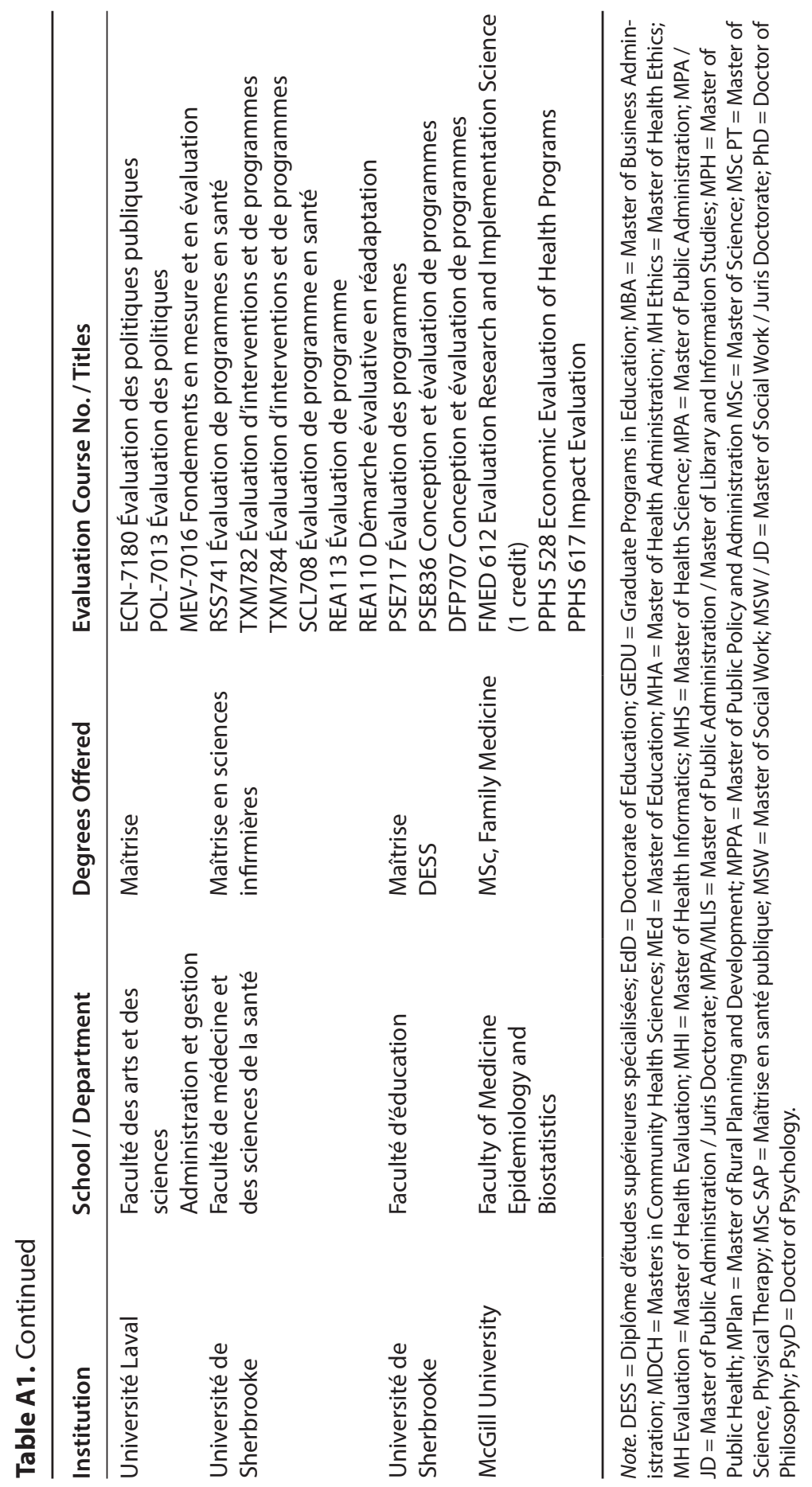

